\title{
PENGARUH MODEL PEMBELAJARAN RECIPROCAL TEACHING TERHADAP PEMAHAMAN KONSEP MATEMATIKA SISWA KELAS VIII SMP NEGERI 4 AMLAPURA
}

\author{
N. M. Sanistiawati ${ }^{1}$, N. N. Parwati ${ }^{2}$, I. P. P Suryawan ${ }^{3}$ \\ Jurusan Pendidikan Matematika Universitas Pendidikan Ganesha \\ Singaraja, Indonesia \\ e-mail: tiasanis@gmail.com ,parwatimat@gmail.com, pasek.suryawan@yahoo.co.id
}

\begin{abstract}
Abstrak
Penelitian ini bertujuan untuk mendeskripsikan pengaruh model pembelajaran Reciprocal Teaching terhadap pemahaman konsep matematika siswa. Jenis penelitian ini adalah eksperimen semu (quasi experimental) dengan desain penelitian Post-Test Only Control Group Design. Populasi penelitian ini adalah seluruh siswa kelas VIII SMPN 4 Amlapura tahun ajaran 2017/2018 yang berjumlah 200 orang dan tersebar ke dalam 7 kelas. Pengambilan sampel dilakukan dengan menggunakan teknik cluster random sampling. Data pemahaman konsep matematika siswa dikumpulkan menggunakan tes pemahaman konsep bentuk uraian. Rata-rata skor pemahaman konsep matematika untuk kelompok eksperimen adalah 24,034 dan rata-rata skor pemahaman konsep matematika untuk kelompok kontrol adalah 19,896. Data dianalisis menggunakan uji- $t$ satu ekor (ekor kanan) dengan taraf signifikan $5 \%$. Hasil pengujian hipotesis menunjukkan bahwa $t_{\text {hitung }}=2,858$ lebih dari $t_{\text {tabel }}=1,672$, sehingga $H_{0}$ ditolak. Berdasarkan hal ini dapat disimpulkan bahwa pembelajaran matematika dengan model pembelajaran reciprocal teaching memberikan pengaruh postitif terhadap pemahaman konsep matematika siswa. Hal ini karena model pembelajaran reciprocal teaching menggunakan empat strategi dalam pelaksanaannya yaitu merangkum, menyusun pertanyaan, mengklarifikasi, dan memprediksi sehingga siswa menjadi lebih aktif dalam bertukar pikiran, mengajukan pertanyaan, mendengar pendapat temannya, dan bersemangat dalam mengikuti pembelajaran dibandingkan dengan siswa yang mengikuti pembelajaran konvensional.
\end{abstract}

Kata kunci: Pemahaman Konsep Matematika, Reciprocal Teaching, Pembelajaran Konvensional

\begin{abstract}
This study aimed at describing the effect of Reciprocal Teaching learning model toward students' mathematical concepts understanding. This study was quasi experimental research with Post-Test design of Only Control Group Design. The population of this study was all $8^{\text {th }}$ grade students of SMPN 4 Amlapura academic year 2017/2018 which amounted to 200 people and spread into 7 classes. Sampling was done by using cluster random sampling technique. The sample of this study was VIII D class which amounted to 29 students as experiment class and VIII C class which amounted to 29 students as control class. Data of students' mathematical concepts understanding was collected using a description test form. The average score of students' mathematical concepts understanding for the experimental group was 24,034 and the mean score of students' mathematical concepts understanding for the control group was 19,896. Data were analyzed by using t-test one-tailed (right tail) with $5 \%$ significant level. The results of the hypothesis test showed that $t_{\text {hitung }}=2,858$ more than $t_{\text {tabel }}=1,672$, so $H_{0}$ was rejected at $5 \%$ significant level. Based on this, it can be concluded that the learning of mathematics with reciprocal teaching learning model gives a positive effect on students' mathematical concepts understanding. This is because the learning model of reciprocal teaching uses four strategies in its implementation which consists of summarizing, compiling questions, clarifying, and predicting so that students become more active in brainstorming, asking questions, hearing opinions of their friends, and eager in following learning compared to students who follow conventional learning.
\end{abstract}




\begin{abstract}
Keywords: Mathematical Concepts Understanding, Reciprocal Teaching,
\end{abstract} Conventional Learning

\section{PENDAHULUAN}

Matematika merupakan ilmu universal yang mendasari perkembangan teknologi modern, mempunyai peran penting dalam berbagai disiplin, dan memajukan daya pikir manusia (BSNP, 2006). Matematika merupakan ilmu yang mempelajari mengenai pola dan hubungan yang bersifat abstrak. Jadi untuk mempelajari matematika harus dimulai dari pemahaman konsep-konsep dasar yang dimulai dengan pengkonstruksian pada masalah kehidupan nyata dan menjadikan pembelajaran matematika menjadi lebih bermakna.

Banyak siswa yang beranggapan bahwa matematika merupakan pelajaran yang tidak menarik dan membosankan karena harus menghafalkan berbagai rumus. Padahal sebenarnya matematika bukanlah sebuah pelajaran menghafal, namun dalam mempelajari matematika siswa memerlukan pemahaman konsep dari setiap materi yang dibelajarkan. Dengan demikian, salah satu kemampuan yang perlu dikembangkan dengan optimal guna mencapai tujuan pembelajaran matematika adalah pemahaman konsep matematika. Hal ini dikarenakan kemampuan memahami konsep merupakan hal yang paling mendasar dalam pembelajaran matematika dan menjadi prasyarat untuk menguasai materi atau konsep berikutnya. NCTM Principles and Standars for School Mathematics (2000) menyatakan "Students must learn mathematics with understanding, actively building new knowledge from experience and priior knowlegde." Artinya, siswa harus belajar matematika dengan pemahaman, secara aktif membangun pengetahuan baru dari pengalaman dan pengetahuan sebelumnya.

Hasil penelitian Trends in Interational Mathematics and Science Study yang disingkat dengan TIMSS menunjukkan bahwa prestasi matematika dan sains Indonesia berada di urutan ke 38 dari 45 negara. Hasil survey ini mempertegas posisi Indonesia relatif masih rendah dengan skor 386 dibandingkan dengan negara-negara lain yang juga berpartisipasi dalam TIMSS. Skor yang diperoleh ini mengalami penurunan jika dibandingkan dengan tahun 2007, dimana saat itu Indonesia menempati peringkat 33 dari 49 negara dengan skor 397. Standar rata-rata pencapaian yang digunakan TIMSS dalam studi ini adalah 500. Rata-rata presentase jawaban benar siswa Indonesia pada survey TIMSS tahun 2011 yaitu: 31\% untuk pengetahuan, $23 \%$ untuk penerapan, dan $17 \%$ untuk penalaran. Rata-rata tersebut pun jauh dibawah rata-rata jawaban benar internasional yaitu: $49 \%$ untuk pengetahuan, $39 \%$ untuk penerapan, dan $30 \%$ untuk penalaran. Soal-soal pada TIMSS dirancang sedemikian rupa sehingga materi dan kognitif siswa dapat teramati, selain itu soal-soal matematika dalam studi TIMSS mengukur tingkat kemampuan siswa dari sekedar mengetahui fakta, presedur atau konsep, lalu menerapkan fakta, prosedur atau konsep tersebut hingga menggunakannya untuk memecahkan masalah yang sederhana sampai masalah yang memerlukan penalaran tinggi.

Hasil dari studi TIMSS yang rendah tentunya disebabkan oleh berbagai faktor. Salah satu faktor penyebabnya adalah pemahaman konsep matematika siswa yang masih rendah. Hal tersebut karena pemahaman konsep merupakan dasar dari belajar matematika. Pemahaman konsep matematika merupakan hal yang penting karena dalam belajar matematika siswa harus mampu memahami konsep matematika terlebih dahulu agar dapat menyelesaikan soal-soal dan mampu mengaplikasikan pembelajaran tersebut ke dunia nyata. Konsep-konsep dalam matematika terorganisasikan secara sistematis, logis, dan hirarkis dari yang paling sederhana ke yang paling kompleks.

Pemahaman konsep merupakan dasar untuk belajar matematika secara bermakna. Konsep matematika merupakan 
ide abstrak yang memungkinkan untuk mengklasifikasikan objek atau peristiwa serta mengklasifikasikan apakah objek dan peristiwa tersebut termasuk atau tidak termasuk ke dalam ide abstrak tersebut (Hudojo, 2003). Jadi dari pemaparan tersebut pemahaman konsep matematika adalah kemampuan dalam memahami ide abstrak untuk mengklasifikasikan objekobjek atau peristiwa-peristiwa dalam matematika. Dalam belajar matematika peserta didik harus memahami konsep matematika terlebih dahulu agar dapat menyelesaikan soal-soal dan mampu mengaplikasikan pembelajaran tersebut ke dunia nyata. Mencapai pemahaman konsep matematika yang baik bagi siswa tidaklah hal yang mudah karena kemampuan setiap individu untuk memahami suatu konsep berbeda-beda. Namun demikian, pemahaman konsep ini harus diupayakan dengan maksimal karena jika siswa telah memahami konsep matematika dengan baik maka akan dapat menyelesaikan soal-soal dan hasil belajarnya pun akan meningkat. Pemahaman konsep siswa dapat dioptimalkan dengan cara merencanakan dan menyusun baik perencanaan, media, dan bahan ajar untuk direalisasikan dalam kegiatan pembelajaran (Parwati, Suryawan, Apsari, 2018). Model pembelajaran yang diperlukan adalah suatu model pembelajaran yang dapat mengoptimalkan pemahaman konsep siswa atau dapat dikatakan juga mampu mengoptimalkan kerja otak dalam memahami suatu konsep. Model pembelajaran yang dapat meningkatkan pemahaman konsep siswa adalah model pembelajaran reciprocal teaching.

Model pembelajaran reciprocal teaching adalah model pembelajaran konstruktivis yang dapat merangsang siswa untuk belajar mandiri, kreatif, dan lebih aktif dalam mengikuti kegiatan pembelajaran. Pada pembelajaran reciprocal teaching siswa diberi kesempatan untuk berkomunikasi dan berinteraksi sosial dengan temannya untuk mencapai tujuan pembelajaran, sementara guru bertindak sebagai motivator dan fasilitator dalam proses pembelajaran. Dengan adanya interaksi antara siswa dengan siswa maupun siswa dengan guru, pembelajaran diharapkan bisa lebih fleksibel dan berpusat pada siswa. Menurut Palinscar (Daniels, 1995) dalam reciprocal teaching ditanamkan empat strategi pemahaman mandiri kepada para siswa.

Tahap pertama yaitu merangkum, pada kegiatan ini siswa mempelajari materi secara mandiri, selanjutnya merangkum/meringkas materi tersebut. Rangkuman yang dibuat siswa dapat mengungkapkan kembali apa yang telah mereka baca dalam kata-kata mereka sendiri sehingga siswa bisa memaknai dengan jelas apa yang harus dikuasai. Dengan demikian, siswa membangun pengertiannya sendiri dan dapat meningkatkan pemahamannya.

Tahap kedua yaitu menyusun pertanyaan, dari apa yang telah dirangkum, siswa kemudian membuat pertanyaan. Pertanyaan ini mengungkapkan penguasaan terhadap materi. Siswa dirangsang untuk berpikir dan membuka wawasannya. Melalui tahap ini, siswa juga diajak untuk melihat keterkaitan antara konsep yang sedang dipelajari dengan konsep-konsep sebelumnya karena siswa diminta untuk membuat pertanyaan sehingga akan menumbuhkan rasa ingin tahu siswa terhadap pembelajaran matematika dan melatih siswa agar tertarik terhadap pembelajaran matematika.

Tahap ketiga yaitu mengklarifikasi, pada tahap ini siswa menjelaskan kembali isi materi tersebut kepada pihak lain. Kegiatan ini memberikan kesempatan bagi siswa melakukan unjuk kerja dan melatih kemampuan siswa dalam mengemukakan pendapat, ide dan gagasan. Selain itu, dapat memberikan kesempatan interaksi siswa dengan siswa dan siswa dengan guru dalam diskusi.

Tahap keempat yaitu memprediksi pada kegiatan ini para siswa belajar untuk memprediksi atau menduga mengenai kemungkinan pengembangan materi yang akan dipelajari selanjutnya. Setelah kegiatan presentasi dan pembahasan materi selesai, siswa dapat mengerjakan soal-soal latihan. Selain itu siswa juga dapat mengembangkan materi yang telah dipelajari baik itu dalam hal menyelesaikan permasalahan nyata atau mengaplikasikan 
materi yang telah dipelajari untuk dapat menemukan hal baru.

Berdasarkan penelitian yang dilakukan oleh Suwiasa (2014) yang menyatakan bahwa penerapan pendekatan reciprocal teaching berpengaruh terhadap kemampuan koneksi matematis siswa. Kemampuan koneksi matematis digunakan untuk mempelajari beberapa topik matematika yang saling terkait antara satu dengan yang lainnya. Terdapat beberapa kegiatan yang meliputi koneksi matematis, salah satunya adalah memahami representasi ekuivalen konsep yang sama. Untuk merelialisasikan kegiatan yang meliputi koneksi matematis itulah diperlukan pemahaman konsep matematika siswa. Ketika kemampuan koneksi matematis meningkat, hal itu didasarkan pada pemahaman konsep yang telah meningkat pula sebelumnya. Jadi dapat dilihat keterkaitan antara kemampuan koneksi matematis dengan pemahaman konsep.

Penelitian yang dilakukan Purnama (2017) menunjukkan bahwa kemampuan pemecahan masalah matematika siswa yang mengikuti pembelajaran dengan model pembelajaran reciprocal teaching lebih tinggi daripada kemampuan pemecahan masalah matematika siswa yang mengikuti model pembelajaran konvensional. Dalam memecahkan permasalahan matematika dibutuhkan pemahaman konsep yang baik, sehingga ketika kemampuan pemecahan masalah meningkat hal itu didasarkan pada pemahaman konsep yang telah meningkat pula. Jadi dapat dilihat keterkaitan antara kemampuan pemecahan masalah dengan pemahaman konsep.

Berdasarkan pemaparan dan hasil kajian di atas, maka dipandang perlu dilaksanakan suatu penelitian untuk mengetahui pengaruh penerapan model pembelajaran reciprocal teaching terhadap pemahaman konsep matematika siswa. Dengan demikian dalam penelitian ini digagas sebuah penelitian yang berjudul "Pengaruh Model Pembelajaran Reciprocal Teaching Terhadap Pemahaman Konsep Matematika Siswa Kelas VIII SMP Negeri 4 Amlapura"

\section{METODE}

Penelitian ini merupakan penelitian eksperimen semu (quasi experiment). Rancangan penelitian yang digunakan adalah Post Test Only Control Group Design.

Populasi penelitian adalah seluruh siswa kelas VIII SMP Negeri 4 Amlapura. Banyaknya anggota populasi dalam penelitian ini adalah 200 siswa yang berdistribusi kedalam tujuh kelas yaitu kelas VIII A, VIII B, VIII C, VIIII D, VIII E, VIII F, VIII G.

Penentuan sampel dalam penelitian ini dilakukan dengan teknik cluster random sampling di mana setiap kelas memiliki kesempatan yang sama untuk dipilih sebagai sampel. Sebelum dilakukan pengambilan sampel secara acak, akan dilakukan uji kesetaraan dengan menggunakan uji Analisis Varians (ANAVA) satu jalur. Uji kesetaraan ini dilakukan untuk memperlihatkan bahwa anggota populasi yang digunakan setara. Data yang digunakan dalam melakukan uji kesetaraan ini adalah nilai ulangan akhir semester mata pelajaran matematika siswa kelas VIII semester ganjil tahun pelajaran 2017/2018.

Variabel bebas dalam penelitian ini adalah model pembelajaran reciprocal teaching yang diterapkan pada kelas eksperimen dan pembelajaran konvensional yang diterapkan pada kelas kontrol sedangkan variabel terikat dalam penelitian ini adalah pemahaman konsep matematika siswa.

Sebelum dilaksanakan uji coba tes pemahaman konsep matematika siswa, dilakukan pengujian validitas isi oleh dua orang pakar di bidang matematika yaitu pakar 1 di bidang Penelitian dan Evaluasi Pendidikan serta pakar 2 yaitu bidang Matematical Sciences. Hasil validitas isi menunjukkan bahwa tes kemampuan pemahaman konsep matematika siswa layak untuk digunakan. Hasil dari uji coba menunjukkan bahwa tes pemahaman konsep matematika siswa yang terdiri dari 8 soal uraian dinyatakan valid. Setelah dilaksanakan uji validitas isi, peneliti melaksanakan uji validitas butir tes dengan menguji cobakan tes pemahaman konsep 
matematika kepada siswa kelas IX SMP Negeri 4 Amlapura. Hasil validitas butir tes menunjukkan 8 butir soal pada tes pemahaman konsep matematika valid dan tes tersebut kemudian diuji reliabilitasnya dan diperoleh bahwa reliabilitas tes kemampuan pemahaman konsep matematika sebesar 0,80 tergolong sangat tinggi.

Selanjutnya dari 8 soal yang telah diujicobakan, dipilih 5 soal untuk dijadikan tes post-test untuk kelompok ekperimen dan kelompok kontrol dengan waktu yang telah ditetapkan. Setelah mendapat skor, dilanjutkan dengan pengujian hipotesis.

Sebelum dilaksanakan pengujian hipotesis, data yang diperoleh harus memenuhi uji prasyarat, yaitu:

1. Uji normalitas untuk skor kemampuan pemahaman konsep matematika dengan menggunakan uji Lilliefors.

2. Uji homogenitas varians untuk kedua kelompok dengan menggunakan uji Levene.

Setelah uji prasyarat terpenuhi, data selanjutnya akan dilakukan uji hipotesis penelitian dengan menggunakan Uji t satu ekor. Pengujian dilakukan dengan bantuan Microsoft Excel. Kriteria pengujian untuk nilai $t_{\text {hitung }}$ dibandingkan dengan $t_{\text {tabel }}$ pada taraf signifikansi $5 \%$ dengan derajat kebebasan $\left(n_{1}+n_{2}-2\right)$, apabila nilai $t_{\text {hitung }}>t_{\text {tabel }}$, maka $H_{0}$ ditolak.

\section{HASIL DAN PEMBAHASAN Hasil Penelitian}

Data yang dikumpulkan dalam penelitian ini berupa skor pemahaman konsep matematika yang diperoleh melalui post-test pada akhir penelitian. Dari data tersebut diperoleh bahwa rata-rata skor untuk kelompok eksperimen adalah 24,034 dan rata-rata skor untuk kelompok kontrol adalah 19,896 .

Selanjutnya, untuk mengetahui apakah pemahaman konsep matematika siswa yang mengikuti pembelajaran dengan model pembelajaran reciprocal teaching lebih baik daripada pemahaman konsep matematika siswa yang mengikuti pembelajaran dengan pembelajaran konvensional perlu dilakukan uji hipotesis, namun sebelumnya terlebih dahulu dilakukan pengujian prasyarat terhadap sebaran data yang meliputi uji normalitas dan uji homogenitas. Berikut ini diuraikan mengenai hasil pengujian normalitas dan homogenitas terhadap data tes pemahaman konsep matematika siswa.

Hasil uji normalitas menggunakan uji Lilliefors diperoleh bahwa untuk kelompok eksperimen yaitu $L_{\text {hitung }}=0,090$ kurang dari $L_{\text {tabel }}=0,161$ pada taraf signifikasi $5 \%$, sedangkan untuk kelompok kontrol $L_{\text {hitung }}=0,127$ kurang dari $L_{\text {tabel }}=0,161$ pada taraf signifikasi $5 \%$, sehingga $H_{0}$ diterima yang berarti sampel dari kedua kelompok berasal dari anggota populasi yang berdistribusi normal.

Hasil uji homogenitas menggunakan uji Levene diperoleh nilai $W=10,142$ dan $F_{\text {tabel }}=4,01$ (untuk dk pembilang $=1$ dan $\mathrm{dk}$ penyebut $=56$ pada taraf signifikansi $5 \%$ ). Apabila dibandingkan, nilai $W<F_{\text {tabel }}$ yang berarti tidak terdapat perbedaan varians antara kelompok eksperimen dan kelompok kontrol.

Berdasarkan hasil uji normalitas dan homogenitas varians, diperoleh bahwa sebaran data pemahaman konsep matematika siswa pada kelompok eksperimen dan kelompok kontrol berdistribusi normal dan memiliki varians yang homogen. Selanjutnya uji hipotesis dapat dilakukan dengan Uji t satu ekor (ekor kanan). Hasil analisis hipotesis menunjukkan bahwa $t_{\text {hitung }}=2,858$ lebih dari $t_{\text {tabel }}=1,672$. Sehingga, $H_{0}$ ditolak yang artinya pemahaman konsep matamatika siswa yang mengikuti pembelajaran dengan model pembelajaran reciprocal teaching lebih baik daripada pemahaman konsep matematika siswa yang mengikuti pembelajaran konvensional.

\section{Pembahasan}

Dari hasil pengujian hipotesis terdapat perbedaan rata-rata pemahaman konsep 
matematika antara kelompok eksperimen dan kelompok kontrol. Hal tersebut menunjukkan bahwa pembelajaran dengan model pembelajaran reciprocal teaching lebih baik dari pada pembelajaran konvensional. Hal ini dikarenakan Model pembelajaran reciprocal teaching terdiri dari empat strategi pemahaman mandiri, yaitu merangkum atau meringkas bahan ajar, menyusun dan mengajukan pertanyaan, mengklarifikasi pengetahuan yang diperoleh, kemudian memprediksi materi selanjutnya. Masing-masing tahapan tersebut dapat membantu siswa dalam membangun sendiri pemahamannya terhadap apa yang sedang mereka pelajari.

Pada tahap merangkum siswa dilatih untuk dapat belajar secara mandiri terlebih dahulu dengan membaca materi dan merangkum materi yang sudah dibaca tersebut secara mandiri. Dengan adanya proses merangkum ini secara langsung siswa terlebih dahulu harus membaca materi pelajaran agar dapat memahami materi yang dipelajari serta mampu untuk menyelesaikan permasalahanpermasalahan dengan berbagai penyelesaian alternatif. Selanjutnya, menyusun dan mengajukan pertanyaan.

Pada tahap menyusun dan mengajukan pertanyaan ini siswa dapat mengajukan pertanyaan-pertanyaan penting dan mendiskusikan dalam kelompok masing-masing. Dari tahap ini siswa dapat lebih kritis dalam memahami hal baru. Pertanyaan yang dibuat oleh siswa akan mencirikan seberapa besar penguasaan siswa terhadap materi yang sudah dipelajari. Pada proses pembelajaran guru membagikan LKS ke masing-masing kelompok untuk didiskusikan. Selain menjawab pertanyaan individu, siswa juga diberikan suatu permasalahan yang harus diselesaikan dalam kelompoknya masing-masing.

Tahap ketiga dari model pembelajaran reciprocal teaching adalah mengklarifikasi pengetahuan yang telah diperoleh. Pada tahap ini salah satu perwakilan kelompok diberi kesempatan untuk mempresetasikan hasil rangkuman dan hasil diskusi mereka dalam kelompok. Dalam hal ini, siswa ataupun guru dapat mengklarifikasi kekeliruan pemahaman yang mungkin terjadi terkait dengan materi yang sedang dibahas. Pada tahap ini siswa juga dapat menganalisis dan memilah-milah apa yang sebelumnya sudah mereka pahami tersebut sudah benar atau masih terdapat kesalahan.

Tahap yang terakhir dari model pembelajaran reciprocal teaching yaitu memprediksi. Pada tahap ini siswa belajar untuk memprediksi atau menduga mengenai kemungkinan penerapan materi yang dipelajari dalam kehidupan seharihari. Setelah kegiatan presentasi dan pembahasan materi selesai, siswa dapat mengerjakan soal-soal latihan baik itu dalam menyelesaikan permasalahan nyata atau mengaplikasikan materi yang telah dipelajari. Tahap memprediksi ini akan dapat menyebabkan meningkatnya pemahaman konsep matematika ditinjau dari indikator pemahaman konsep (NCTM, 2000) yaitu siswa dapat menggunakan konsep dengan benar dalam berbagai situasi.

Pembelajaran yang berlangsung di kelas kontrol dilaksanakan dengan menerapkan model pembelajaran konvensional. Pembelajaran dalam bentuk diskusi kelompok berlangsung dalam menemukan informasi-informasi berupa hal-hal pokok atau konsep dari materi yang sedang dipelajari dengan arahan guru. Pemberian kesimpulan terhadap pokok materi atau inti dari pembelajaran diberikan saat pembahasan. Dalam diskusi, hanya beberapa siswa yang membaca buku secara keseluruhan dan mendetail mengenai materi yang sedang dibahas dan menjawab soal pada LKS, sehingga hanya beberapa siswa yang benar-benar memahami penemuan konsep-konsep terhadap materi tersebut. Sementara itu, sebagian siswa lainnya membaca hanya di bagian-bagian yang menjadi pokok materi sehingga kurang memahami konsep secara maksimal dari materi tersebut. Hal tersebut membuat siswa kurang aktif untuk mengoptimalkan kemampuan berpikirnya dan mengkonstruksi pemahaman konsepnya.

Berdasarkan pengamatan peneliti pada saat pembelajaran berlangsung menunjukkan bahwa siswa yang mengikuti 
model pembelajaran reciprocal teaching lebih aktif dalam menggali mengetahuannya dengan merangkum dan berdiskusi menjawab soal bersama kelompoknya, siswa terbiasa diskusi dengan teman kelompoknya dengan saling mengajukan pertanyaan mengenai materi yang dipelajari dan didukung pada tahap mengklarifikasi dimana siswa dapat bertanya dan memberikan pernyataan tentang apa yang sudah mereka pahami kepada kelompok lain. Aktivitas siswa yang lebih positif dan antusias dalam kegiatan belajar menjadi salah satu faktor yang membuat rata-rata skor yang diperoleh siswa di kelas eksperimen lebih tinggi daripada rata-rata skor yang diperoleh siswa di kelas kontrol. Hal ini sejalan dengan penelitian yang dilakukan oleh Suwiasa (2014) yang menyatakan bahwa pendekatan reciprocal teaching berpengaruh positif terhadap kemampuan koneksi matematis siswa. Kemampuan koneksi matematis digunakan untuk mempelajari beberapa topik matematika yang saling terkait antara satu dengan yang lainnya. Ada beberapa kegiatan yang meliputi koneksi matematis, salah satunya adalah memahami representasi ekuivalen konsep yang sama. Untuk merealisasikan kegiatan yang meliputi koneksi matematis itulah diperlukan pemahaman konsep matematika. Ketika kemampuan koneksi matematis meningkat, hal itu didasarkan pada pemahaman konsep yang telah meningkat pula sebelumnya.

Secara umum, pelaksanaan pembelajaran dengan model pembelajaran reciprocal teaching dapat berjalan dengan baik sesuai dengan rencana. Walaupun demikian, dalam pelaksanaannya di kelas tidak luput dari adanya kendala-kendala. Adapun kendala-kendala yang dihadapi yaitu dalam pelaksanaan model pembelajaran reciprocal teaching ini memerlukan manajemen waktu yang baik dalam persiapan maupun pelaksanaan proses pembelajaran, hal ini karena adanya kegiatan membaca dan merangkum materi secara mandiri dimana setiap siswa memiliki kecepatan yang berbeda-beda dalam membaca sehingga harus mengatur waktu dengan baik, siswa masih merasa kebingungan saat model pembelajaran reciprocal teaching ini pertama kali diterapkan sehingga siswa memerlukan waktu untuk terbiasa. Oleh karena itu diperlukan upaya ekstra diawal pembelajaran agar maksud dari model pembelajaran dapat dipahami oleh siswa. Selain itu, pada saat perwakilan kelompok diminta untuk mempresentasikan hasil diskusi kelompoknya di depan kelas, siswa masih terlihat malu-malu untuk menyampaikan kepada siswa lain. Namun kendala-kendala tersebut dapat ditangani dengan baik. Kendala-kendala tersebut dapat ditangani dengan membatasi waktu untuk masing-masing kegiatan agar kekurangan waktu selama proses pembelajaran. Selanjutnya pada setiap awal pertemuan guru harus mengingatkan kembali tahapan-tahapan pembelajaran yang harus dilakukan oleh siswa. Selain itu guru juga memberikan motivasi kepada siswa dengan memberikan petunjuk berupa pernyataan atau pertanyaan yang dapat membuat siswa terpacu lebih aktif dalam berdiskusi bersama dengan kelompoknya.

Berdasarkan hasil pengujian hipotesis dapat dilihat bahwa pembelajaran dengan model pembelajaran reciprocal teaching berpengaruh positif terhadap pemahaman konsep matematika siswa. Hal ini dibuktikan dengan hasil yang menunjukkan bahwa pemahaman konsep matematika siswa yang mengikuti pembelajaran dengan model pembelajaran reciprocal teaching lebih baik daripada siswa yang mengikuti pembelajaran konvensional.

\section{SIMPULAN DAN SARAN Simpulan}

Berdasarkan uraian pada hasil penelitian dan pembahasan, diketahui bahwa terdapat perbedaan pemahaman konsep matematika siswa yang mengikuti model pembelajaran reciprocal teaching dan siswa yang mengikuti pembelajaran konvensional. Pemahaman konsep matematika siswa yang mengikuti pembelajaran dengan model pembelajaran reciprocal teaching lebih baik daripada pemahaman konsep matematika siswa yang mengikuti pembelajaran konvensional. Berdasarkan hal ini dapat 
disimpulkan bahwa pembelajaran matematika dengan model pembelajaran reciprocal teaching memberikan pengaruh positif terhadap pemahaman konsep matematika siswa.

\section{Saran}

Berdasarkan hasil penelitian yang diperoleh, peneliti melalui tulisan ini mengajukan beberapa saran. Saran yang dapat disampaikan adalah sebagai berikut.

1. Kepada peneliti lain yang tertarik, disarankan untuk melakukan penelitian terhadap model pembelajaran reciprocal teaching terhadap domain kemampuan kognitif yang lain untuk mengetahui pengaruh penerapan model pembelajaran reciprocal teaching dalam pembelajaran matematika secara lebih mendalam.

2. Kepada praktisi pendidikan matematika, khususnya guru mata pelajaran matematika diharapkan untuk menerapkan model pembelajaran reciprocal teaching sebagai salah satu alternatif pembelajaran di kelas mengingat pengaruh positif yang diberikan model pembelajaran reciprocal teaching terhadap pemahaman konsep matematika siswa.

\section{DAFTAR PUSTAKA}

Arikunto, S. 2002. Dasar-dasar Evaluasi Pendidikan. Jakarta: Bumi Aksara.

Arikunto, S. 2005. Manajemen Penelitian. Jakarta: Rineka Cipta

BNSP (Badan Standar Nasional Pendidikan). 2006. Standar Isi untuk Satuan Pendidikan Dasar dan Menengah (Standar Kompetensi dan Kompetensi Dasar SMP/Mts). Jakarta

Candiasa, I. M. 2010. Statistik Univariat dan Bivariat Disertai Aplikasi SPSS. Singaraja: Universitas Pendidikan Ganesha.
Candiasa, I. M. 2011. Pengujian Instrumen Penelitian Disertai Aplikasi ITEMAN dan BIGSTEPS. Singaraja: Universitas Pendidikan Ganesha.

Dimyati dan Mudjiono. 1999 . Belajar dan

Pembelajaran. Jakarta: Rineka Cipta.

Huda, M. 2014. Model-model Pengajaran dan Pembelajaran: Isu-isu Metodis dan Paradigmatis. Cetaka n ke-5. Yogyakarta: Pustaka Pelajar.

Hudojo, H. 2003. Common Textbook: Pengembangan Kurikulum dan Pembelajaran Matematika. Malang: IMSTEP

Kementrian Pendidkan Nasional. 2011. Instrumen Penilaian Hasil Belajar Matematika SMP: Belajar dari PISA dan TIMSS. Jakarta: Pusat Pengembangan dan Pemberdayaan Pendidik dan Tenaga Kependidkan (PPPPTK) Matematika.

NCTM. 1989. Curriculum and Evaluation Standard for School Mathematics. Virginia: The NCTM Inc.

NCTM. 2000. Principke and Standards for School Mathematic. Virginia:NCTM.

Palinscar, A. (1986). Strategies for Reading Comprehension Reciprocal Teaching. Tersedia http://curry.edschool.virginia.edu/g o/readquest/strat/rt.html. (diakses tanggal 4 Februari 2018)

Parwati, N.N, Suryawan, I.P.P. \& Apsari, R.A. 2018. Belajar dan Pembelajaran. Jakarta: Rajawali Pers.

Purnama, I. M. C. A. 2017. Pengaruh Pendekatan Reciprocal Teaching Terhadap Kemampuan Pemecahan Masalah Matematika Siswa Kelas X 
Akuntansi SMK Negeri 1 Singaraja.

Skripsi Jurusan Pendidikan

Matematika FMIPA UNDIKSHA:

tidak diterbitkan.

Sugiyono. 2015. Metode Penelitian Pendidikan (Pendidikan Kuantitatif, Kualitatif, dan R\&D). Bandung: Alfabeta

Sugiyono. 2010. Statistika Untuk Penelitian. Bandung: Alfabeta

Suryawan, I. P. P. 2010. Penerapan Model Pembelajaran Terbalik (Reciprocal Learning) untuk meningkatkan Pemahaman Konsep Matematika Siswa Kelas VIIG SMP Negeri 5 Singaraja. Skripsi Jurusan Pendidikan Matematika FMIPA UNDIKSHA: tidak diterbitkan.

Suwiasa. 2014. Pengaruh Pendekatan Reciprocal Teaching terhadap Kemampuan Koneksi Matematis Siswa Kelas X IPA SMA Negeri 8 Denpasar. Skripsi Jurusan Pendidikan Matematika FMIPA UNDIKSHA: tidak diterbitkan.

TIMSS (Trend in Mathematics and Science Study). 2011. Mathematics Framework. Jurnal TIMSS, Volume 1(hlm. 1-27).

Trianto. 2007. Model-model Pembelajaran Inovatif Berorientasi Konstruktivistik. Jakarta: Prestasi Pustaka.

Uno, H B. 2012. Model Pembelajaran Menciptakan Proses Belajar Mengajar yang Kreatif dan Efektif. Jakarta: Bumi Aksara. 